\title{
SUSTAINABILITY OF AGRICULTURAL FARM FINANCING IN THE REPUBLIC OF SERBIA
}

Ivana Ljubicic ${ }^{1}$, Danijela Radenkovic ${ }^{2}$, Ivan Bulatovic ${ }^{3}$

*Corresponding author E-mail: ivana.ljubicic@bpa.edu.rs

A R T I C LE I N F O

Review Article

Received: 01 November 2019

Accepted: 10 December 2019

doi:10.5937/ekoPolj1904201L

UDC 336.15:631.1.017.3(497.11)

Keywords:

small and medium-sized enterprises, agriculture, incentives

JEL: Q16, M24

\section{A B S T R A C T}

Small and medium-sized enterprises, as well as entrepreneurs in agrobusiness, make a major contribution to the economic growth and development of a country's economy. The current legislative and executive branches of government create fiscal policy of a country, which plays a significant role in supporting entrepreneurship. In a way, farms can be considered as a form of SME, because no agricultural farm, except privatized but previously fragmented agricultural combines, falls into the category of large enterprises or large farms. The state should promote the integration of new technologies and farmers should be provided training for the adoption of technologies, and given grants for innovations which is also the subject of research in this paper.

(C) 2019 EA. All rights reserved.

\section{Introduction}

Agricultural companies in the Republic of Serbia has a smaller number of full-time employees and operate with relatively low capital employed. The main problem these farms face is certainly the lack of financial resources, especially if it involves a specific production process and a slow turnover of funds and especially if we now that agriculture makes a very significant contribution to the development of national economies (Pjanić et al., 2018).

Activities of small and medium-sized farms must be harmonized with the applicable legal regulations. The interaction between these businesses and the natural environment in the long run must be based on survival with acceptable production growth.

1 IvanaLjubičić, MA, Belgrade Business Academy for Applied Studies, Kraljice Marije br.73, Belgrade Serbia, Phone: +381 11 3042-311, E-mail:ivana.ljubicic@bpa.edu.rs, https:// orcid.org/0000-0002-5493-1690

2 Prof. Danijela Radenković, PhD, Belgrade Business Academy for Applied Studies, KraljiceMarije br.73, Belgrade, Serbia, Phone: +381 11 3042-377, E-mail: danijela. radenkovic@bpa.edu.rs, https://orcid.org/0000-0001-6539-1979

3 Prof. Ivan Bulatović, PhD, Belgrade Business Academy for Applied Studies, KraljiceMarije br.73, Belgrade, Serbia, Phone: +381 11 3042-377, E-mail: ivan.bulatovic@bpa.edu.rs, https://orcid.org/0000-0002-5107-6289 
Agricultural entrepreneurs plays major role in the growth and development of national economies and the reduction of poverty. Success depends largely on the institutional support that a particular country provides through its mechanisms. Serbia is faced with low levels of economic activity, high unemployment rates, low investment and competitiveness rates, mainly large, inefficient state and public enterprises, and the development of small and medium-sized enterprises and agricultural entrepreneurs is a great development opportunity for it.

Another problem is the problem of land ownership and difficulties in the formal registration of immovable property. The possibility of free access to the real estate market, and first and foremost to construction land, is very important for the development of entrepreneurship. Serbia has some limitations here that do not exist in the developed world. The issue of restitution is still unresolved.(Financing of small and medium enterprises, 2012)

The real estate catastre is very poor and it seriously blocks many entrepreneurial opportunities. As a result, many entrepreneurs are unable to obtain mortgage loans as a source of funds for starting a business.(Milojević \& Mihajlović, 2019)

When the growth phase, which is very demanding financially, occurs, the funds of the entrepreneur himself are mostly already exhausted and financing from external sources becomes important. Loans and venture capital are becoming an increasingly attractive source of financing. A loan is an expensive source of financing for SMEs, farms and entrepreneurs. Banks are not willing to lend to farms because they are at high risk of not being able to return the funds. Also, this type of financing is accompanied by high administrative and processing costs, and farms do not usually have adequate accounting records, business plans and financial statements.

\section{Research methodology}

The research methodology aims to analyze the role of financial mechanisms in the sustainability of financing farms. It covers the descriptive method and content analysis of available literature by reference national and foreign authors. Using this methodology, we will emphasize the importance of financing on the quality of sustainability of management and business efficiency of agricultural holdings, with the use of innovations as a basis for the success of modern business systems.

\section{Farms in the modern economy}

Today's business is characterized by highly industrialized production, increasingly stringent regulations in the field of consumer protection, the ever-increasing and everexpanding demands of the consumer society, all of which affect the survival of businesses. Rapid technological development and economic growth, rapid implementation of new developments, increasingly complex business, and the need for adaptation and planning are just some of the hallmarks of competitive struggle. 
Small and medium-sized enterprises and entrepreneurs, as well as farms, play a significant role in the economy of our country, because by improving the quality of goods, services and competitiveness in the market, they are more adaptable to changes, innovations and new technologies, compared to state-owned enterprises. Some segments of their comparative advantages in the market are their small size, which makes them more flexible, and tradition, which allows them to have a long experience in the production process as well as knowledge of the distribution chain based on old contacts.

One part of the problem stems from the education system, poor encouragement of entrepreneurial thinking and the placement of young people's ideas for starting their own businesses, while one part may be attributed to the heritage of 45 years of socialism and the previous heritage of 200 to 500 years of Ottoman rule, depending on the part of Serbia we are talking about. Neither the communist ideology nor the Turkish system of government were benevolent to capitalist entrepreneurial initiatives, but almost exclusively promoted the idea of petty entrepreneurship and craft that was either passed from generation to generation or was simply too small to create a prevalent entrepreneurial spirit in citizenship that would try to enforce the creation of an entrepreneurial-oriented society. As far as farms are concerned, they existed in socialism, unlike in other, much more restrictive countries, such as the Soviet Union, but their size was limited to 10 hectares, or 17 acres. This did not have a positive effect on the development of entrepreneurial culture, but the fairly equal farmers were networked in secure distribution chains through state-owned agricultural combines, which were particularly effective in the Pannonian lowlands (Vojvodina, Belgrade and northern Central Serbia).

SMEs are a leading force in the economic development of each country.(Domínguez-Torreiro \& Soliño, 2015; Đokić, 2018) They empower the economy in many ways: they target specific areas of the market and consumers, they respond more quickly to the emergence of opportunities and threats that they perceive in the environment, they adapt more quickly to change, they are more flexible, they represent a good source of entrepreneurial and innovative ideas, they create jobs. As a result of the development of the Internet and telecommunications technologies, SMEs are increasingly contributing to the globalization of business.

The advantage of these companies is that they can meet specific or periodic needs for certain products that are needed in smaller quantities, operate more efficiently and faster when it comes to changing the organizational structure in line with market dynamics.

The disadvantages of small and medium-sized enterprises are a lack of resources, primarily financial resources, as well as knowledge and institutional infrastructure. (Brankov \& Lovre, 2017) Management in these enterprises takes the form of management of an enterprise but with limited resources. In a way, farms can be considered as a form of small and medium-sized enterprise, because no agricultural farm, except privatized but previously fragmented agricultural combines, falls into the category of large enterprises or large farms, such as those in North America, or those of latifundia in Latin America. Therefore, the experience of small and medium-sized enterprises is largely applicable to all aspects of the farm business. 


\section{Financing of agricultural farms}

Farms are characterized by labor-intensive processes that have an impact on reducing income inequality, resulting in a drop in poverty. In this sphere, jobs are created for people from more modest backgrounds, women and other groups who do not have too many job opportunities. ). In practice, the tax is also considered to be an instrument for securing necessary budget funds, but it is also used for achieving other goals (Rapajić et al., 2019). Good is example of author Macháček (2017) who proposed effective business support tools at the region and municipality level.

The agricultural sector also contributes to a better allocation of resources. Harmony is established between the abundance of labor and scarce capital. Also, participatin ih highly automated society can be one of solutions (Vochozka et al., 2018; Popescu, 2018) and cognitive technology-driven automation (Hardingham et al., 2018) will change future of work (Neary et al., 2018; Hyers \& Kovacova, 2018; Koppel \& Kolencik, 2018; Taylor \& Kliestikova, 2018; 32. Tuyls \& Pera, 2019). It contributes to better geographical allocation, the distribution of entrepreneurial ideas, and the reduction of the economic gap between poor rural and affluent urban areas. Also, Blažević et al. (2018) said that rural and eco-tourism has been emerging as a way for revitalizing villages. Development potentials of agricultural holdings are (Botezatu \& Andrei, 2012):

- Rapid adoption of new technologies

- Rapid adoption of new management styles and management methods

- Fast learning and development

- Risk taking

- Flexibility

- Specialization opportunity

- Adaptation to consumer requirements

- Quick communication with the market

These businesses are more dynamic and adaptable than big ones. Their disadvantages are(Done et All., 2012):

- They are too small to produce the effects of the economies of scale

- Lower productivity

- They do not have the opportunity to internationalize their business

- They cannot carry out complex business ventures

The basic problem that prevents and slows down the development of entrepreneurship is the insufficient separation of the economic environment. Numerous administrative barriers are present, followed by complicated procedures. The 2015 World Bank Business Report confirms that there has not been sufficient work done in Serbia to 
improve the economic environment. Serbia ranks 91 st out of 189 countries in the ranking of countries ranked according to this criterion. The year before, it had taken the place of 93. There is some progress, but is very slow.(Vujicic, \& Ristić, 2012)

First of all, there are problems of financing; it is difficult to collect receivables, there is a high credit indebtedness (Serbia has the highest interest rates in the region accompanied by high banking costs, and another problem is also the issue of securing loans as well as limited amounts of loans). About $80 \%$ of entrepreneurs settle their obligations to suppliers within a period of less than 45 days, while about $57 \%$ manage to collect their claims within the same period. In the construction sector, the longest payment is expected, with as much as $54 \%$ waiting over 45 days. The following is a wholesale business where every other firm waits longer than 45 days to receive their money. This is very disadvantageous for farms that have their own production or licensed brands (organic food, dairy products, etc.).

The most important sources of financing a business is personal funds, especially when it comes to financing working capital and investments. If external funds are used, they are mostly bank loans and they participate in the financing structure at $35 \%$. They are followed by overdrafts with a share of $8 \%$ and loans from friends that make up $7 \%$.

There are problems with the enforcement process related to its efficiency and cost. The problem is the lack of adequate collaterals and frequent changes to the existing regulations and procedures.

Agricultural entrepreneurs and small and medium-sized enterprises mostly serve the local markets, followed by the markets of Serbia and the Region. As many as $81 \%$ of firms have not patented any form of intellectual property, and those who have patented it most commonly protected their trademark and the industrial design. The main problems related to the issue of market competitiveness are quality and price, which results in a lower export orientation and the creation of innovative products of higher processing stages.(Tasić, 2018)

The most important market constraints are strong competition and weak demand. Public procurement is practically inaccessible to agricultural companies.(Cremer-Schulte \& Dissart, 2015) A large number of small firms do not have a developed sales network or a strategically planned pricing policy, so they balance sales and the delivery of goods.

Another problem is the average age of equipment, which is about 5-10 years, while every fourth company works with equipment that is more than 10 years old. Older equipment is mainly owned by manufacturing and agricultural enterprises, as well as medium-sized enterprises from the non-agricultural sector.

The highest investments are related to the procurement of equipment, then to business premises, and the least is invested in patents and licenses. Every fourth company has quality standards and certificates, while only one in ten have plans to introduce them at all. The largest number of certificates are held by medium-sized enterprises in the sphere of production and processing, computer and information technology, catering and recycling. Mainly ISO 9001 and HASSP standards. 


\section{Innovation and human resource}

Republic of Serbia is in a group of less developed European countries and its development is not driven by knowledge and innovation. The importance and role of knowledge and innovation in the development of the Serbian economy is low, the innovation of domestic SMEs is weak because very few SMEs innovate. The growth in the number of SMEs is not accompanied by the growth of innovation that would provide a competitive advantage that is sustainable in both the domestic and global markets. The same conclusions can be drawn for farms.

Figure 1. Performance of EU member states innovation systems

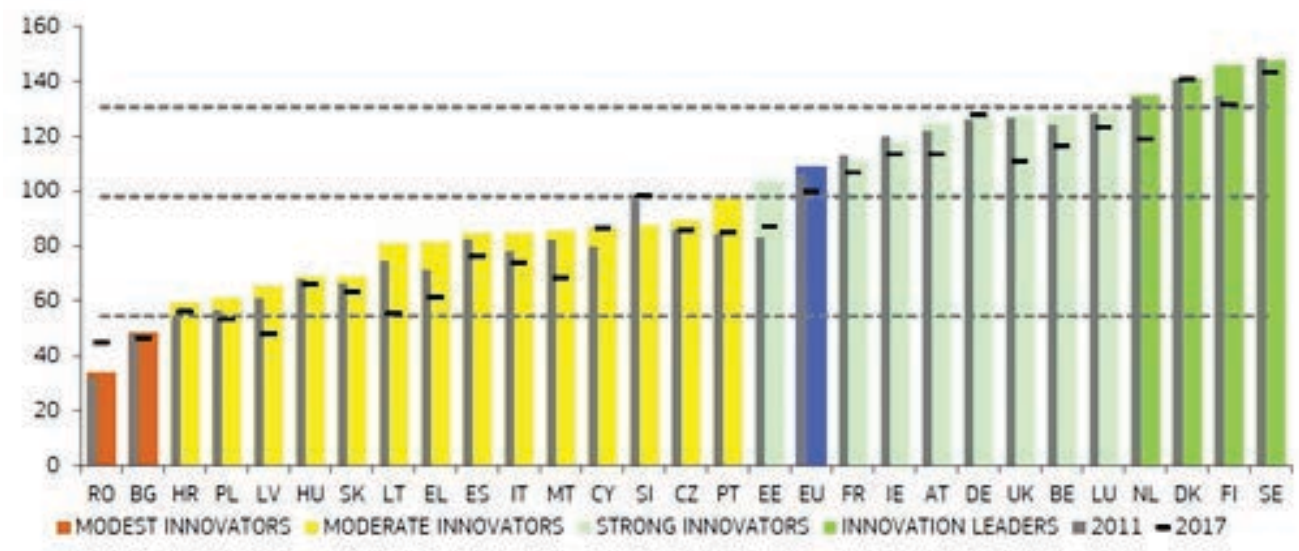

Source: European Inovation Scoreboard 2017

A very important factor in the development of entrepreneurship are human resources. Characteristics of the labor market in Serbia are: disharmony of labor supply and demand, mismatch in the qualification, age and professional structure of the staff, long-term unemployment, a large number of young people from 15 to 24 who are unemployed, high unemployment of people with lower and secondary education, as well as large regional disproportions.(Stanojević, Mišković, \& Jeftić, 2017; Nica, 2017; Nica et al, 2017; Nica, 2018).

They are otherwise the most important resource in the economy, but limited. The reasons are that demographic flows are, above all, unfavorable. The population is getting older, a lot of people are moving to more developed countries, birth rate is low. This leads to the depopulation of a country, and depopulation is most pronounced in agricultural centers.(Mićović \& Miletić 2019; Stanojević, Đorđević, \& Volf, 2017) At the time of sanctions, during the 1990s, villages and the agricultural sector were the richest part of the country on which not only development but the very survival of the state and the people were based, while today it is quite the opposite - agriculture is the branch that is most regressing. Another problem is the unenviable structure of education. Serbia has a high illiteracy rate and a low percentage of highly educated people - about 7-8\%. Another problem is the health of the nation, both physically and mentally, which is also low. 


\section{Physical capital and historical perspective}

In order to achieve the most successful development of entrepreneurship, we especially emphasize the need to use the scarce financial (budgetary) means and funds, in a purposeful, rational and economically justified way.(Popescu, 2014)

Serbia has solid physical capital - arable land, meadows, pastures, forests, water, as well as human capital. Only the financial capital is limited. For this reason, the management of financial capital must be sharpened, primarily through intended and rational use, as well as monitoring its effect in a short and long term.

Economic growth and development has taken place in an attempt to achieve, at the same time, the growth of personal and public consumption growth, to positively influence growth and increase employment. Market reforms, privatization and the attracted foreign investment have been carried out in order to create the institutional and material prerequisites for stable economic development.(Oostindie, 2015)

However, only partial results were achieved because GDP did not achieve sufficient growth, and due to the negligent use of rising GDP, foreign trade imbalance increased, as foreign trade and current wage deficits increased. In the years 2001-2008, the so-called years of transition, there was a rise in real wages as a result of foreign donations, economic subsidies and appreciation of the dinar. This did not increase employment, but unemployment. The inflow from the sale of state and former social capital was used to a large extent to finance the balance of payments deficit and the budget deficit, with the services sector favored over the manufacturing sector.( Milojević, Mihajlović, \& Vladisavljević, 2018)

Such a policy certainly did not lead to the creation of a stimulating economic environment, but rather a decline in the initial expansion of a competitive private sector. After the unsuccessful transition, the global economic crisis occurred which, as a consequence, brought about: rising unemployment rates, rising poverty, fall in demand, impoverishing population, declining purchasing power of people. At the same time, the SME sector encountered problems in the form of lack of funds, complicated laws and procedures, lack of essential information on technologies and markets, qualified personnel, non-compliance with standards, etc.

The biggest problem was the limited access to funding sources in the money and capital markets. Firms had to rely primarily on their own resources, which were insufficient and could not meet the growing needs for capital, which occurred especially in the later stages of their life cycle.

Regarding bank loans, the biggest problems were(Milosavljević, Pantelejić \& Međedović, 2019):

- Lack of funds to secure loans

- Lack of documentation on company and business ventures

- Lack of competencies to properly present the project to creditors 
Creditors focused on financing large enterprises, lacking a methodology for evaluating small projects, which made the assessment expensive, especially when compared to small individual loan amounts (Paunović, 2017; Naldi, 2015). Fundraising on the stock market through initial public sale of shares was problematic, as the companies here are simply not attractive to investors. The SME sector is an "oasis" of national economic sovereignty and a potential lever for development economic policy, for countries like Serbia (Stamatović, 2013).

National economies of weak states are not and cannot be equal partners to multinational and global companies and giants. Creating a conducive institutional framework and stimulating business environment is a challenge faced by policy makers and decision makers in all countries that have become aware of the role and importance of the SME sector. This applies particularly to developing and transition countries.

More then $1 \%$ of SMEs and farms says that they mainly use non-banking sources of financing, such as, for example, leasing. Although close to $1 / 3$ of the firms have received funding from state programs, only $2 \%$ of SMEs and farms claim that the state is their main financier. There are also gender differences among funding beneficiaries.

A very low percentage of financing appears to be used for investment. About $80 \%$ of SMEs state that they borrow to invest in current assets and for other short-term needs. Dedicated loans are commonly used.

Long-term loans cover only $15-25 \%$ of fixed assets, most of fixed assets are not financed from external sources. The leverage of the MPS sector is not adequate. The average debt to equity ratio is less than 1.7 . This is much less than considered the normal debt threshold in other developed markets. The normal debt threshold is considered to be between 1.5 and 2. Low leverage indicates that firms finance their operations from internal or informal sources.

Credit products and services are not properly aligned with the needs of firms. Firms are the least satisfied with interest rates and fees. They find that they are too high and discourage from taking loans. Firms are not satisfied with the quality or efficiency, as well as the time required to obtain a loan.

\section{Conclusion}

When it comes to equity, the following resources are available to farms: personal resources, resources of family and friends and investors.

When a company is at the beginning of its life cycle, there are not many available sources of financing. Data on financial and other features of business ventures are limited, so it is difficult to attract external financiers. Credit ability is poor when a company is young.

As a business grows older and larger, the number of funding sources grows. In the early stages, the company is usually financed from its own resources and those of family 
and friends, and then opportunities arise to access external capital - investment funds, business angels, bank loans, etc.

Access to finances also depends largely on the type of firm, whether it is a traditional enterprise that aims to provide income for an individual, family, and a small group of employees, or whether it is an innovative enterprise that has high growth potential.

As we have said, in the first stages farms rely on personal and family resources, while loans from banks and other financial institutions are only taken if absolutely necessary, since borrowing is very risky at this stage. The risk is high and the outcome is uncertain. Loans are also accompanied by high costs.

Another source of funding are various state support programs for beginners in business. When an entrepreneur has some innovative idea and concept, he or she may have access to business angels who are a more affordable and accessible source than obtaining finance from formal investors.

\section{Conflict of interests}

The authors declare no conflict of interest.

\section{References}

1. Botezatu, M., \& Andrei, J. (2012). Implications of the environmental factors on the economic efficiency of capital investments. A Romanian perspective in terms of a sustainable economy. Journal of Environmental Protection and Ecology, 13(1) 382-391

2. Blažević, M., Peters, K., \& Chen, G. (2018). Developing rural tourism in minority ethnic villages: Zlot and Xiaocang She Ethnic Township. Hotel and Tourism Management, 6(2), 71-78. https://doi.org/10.5937/menhottur1802079B

3. Brankov, T., \& Lovre, I. (2017). Food security in the former Yugoslav republics. Ekonomika poljoprivrede, 64(2), 701-721.

4. Cremer-Schulte, D., \& Dissart, J.C., (2015). Evaluating rural development in French Regional Nature Parks. Journal of Environmental Planning and Management, 58(3), 383-403

5. Done, I., Chivu, L., Andrei, J., \& Matei, M. (2012). Using labor force and green investments in valuing the Romanian agriculture potential. Journal of Food Agriculture \& Environment, 10 (3\&4), 737-741

6. Domínguez-Torreiro, M., \& Soliño, M. (2015). Measuring social preferences for rural development in Southern Europe. International Journal of Environmental Research, 9(1), 27-34

7. Đokić, I. (2018). Economic effects of integrated marketing communications: The case of food products. Ekonomika poljoprivrede, 65(3), 985-994. 
8. Financing of small and medium enterprises, recommendation book, USAID, Serbia, 2012

9. Hardingham, E., Vrbka, J., Kliestik, T., \& Kliestikova, J. (2018). Will Cognitive Technology-Driven Automation Lead to Economic Growth?. Journal of SelfGovernance and Management Economics, 6(4), 13.

10. Hyers, D., \& Kovacova, M. (2018). The economics of the online gig economy: Algorithmic hiring practices, digital labor-market intermediation, and rights for platform workers. Psychosociological Issues in Human Resource Management, 6(1), 160-165.

11. Koppel, J., \& Kolencik, J. (2018). The future of workers: Contingent forms of labor contracting in the platform economy. Psychosociological Issues in Human Resource Management, 6(1), 172-177.

12. Macháček, J. (2017). Promoting entrepreneurship on the part of municipalities. Revista» Administratie si Management Public «(RAMP), (29), 74-90.

13. Milojević, I., \& Mihajlović, M. (2019). Implementation of the method of assessing investment projects in the public sector. Oditor - časopis za Menadžment, finansije i pravo, 5(1), 19-31.

14. Milosavljević, S., Pantelejić, Đ., \& Međedović, D. (2019). Primena i mogućnost unapređenja ekonomskih činilaca u realizaciji održivog razvoja. Održivi razvoj, 1(1), 7-14. [in English: Application and possibility of improvement of economic factors in realization of sustainable development. Sustainable Development]

15. Mićović, S., \& Miletić, J. (2019). Poslovni subjekt kao osnova održivosti razvoja. Održivi razvoj, 1(1), 41-49. [in English: Business entity as a basis for sustainability of development.. Sustainable Development]

16. Milojević, I. M., Mihajlović, M. B., \& Vladisavljević, V. D. (2018). Methodological aspect of controlling corporate income tax. Vojno delo, 70(1), 103-111.

17. Naldi, L., Nilsson, P., Westlund, H., \& Wixe, S. (2015). What is smart rural development? Journal of Rural Studies, 40, 90-10

18. Nica, E. (2017). Techno-pedagogy knowledge in smart learning environments. Economics, Management, and Financial Markets, 12(1), 75-81.

19. Nica, E., Comănescu, M., \& Manole, C. (2017). Digital reputation and economic trust in the knowledge labor market. Journal of Self-Governance and Management Economics, 5(3), 83.

20. Neary, B., Horák, J., Kovacova, M., \& Valaskova, K. (2018). The future of work: Disruptive business practices, technology-driven economic growth, and computer-induced job displacement. Journal of Self-Governance and Management Economics, 6(4), 19-24.

21. Nica, E. (2018). Gig-based working arrangements: Business patterns, labormanagement practices, and regulations. Economics, Management, and Financial Markets, 13(1), 100-105. 
22. Oostindie, H., Van Broekhuizen, R., Soldaat, B., \& Van Der Ploeg, J.D. (2015). Towards the characterization of actors engaged in rural development processes in the north west of Europe. Research in Rural Sociology and Development, 22, 239254

23. Paunović, G. (2017). The role of small and medium-sized enterprises and entrepreneurship in the development of national economy. Ekonomija: teorija $i$ praksa, 10(1), 44-63.

24. Pjanić, M., Vuković, B., \& Mijić, K. (2018). Analysis of the market concentration of agricultural enterprises in AP Vojvodina. Strategic Management, 23(4), 40-45. DOI:10.5937/StraMan1804040P

25. Popescu, G.H. (2014). The economic impact of rising temperatures. Journal of Self-Governance and Management Economics, 2(1), 44-49

26. Popescu, G. H. (2018). Participation in the sharing economy: Labor, exchange, and consumption. An empirical analysis. Journal of Self-Governance and Management Economics, 6(1), 122-127.

27. Rapajić, M., Lapčević, M., \& Miladinović, V. (2019). Dinamism of property tax reform in Serbia: Administrative and fiscal aspects. Ekonomika, 65(1), 35-46.

28. Stamatović, M.LJ. (2013). Business performance management of SMEs. Novi Sad: University of Economics Academy

29. Stanojević, S., Đorđević, N., \& Volf, D. (2017). Applying the machine learning method in predicting business winners vs. losers through financial reports. Oditor časopis za Menadžment, finansije i pravo, 3(1), 92-101.

30. Stanojević, P., Mišković, V., \& Jeftić, Z. (2017). Contemporary interpretation of the concept of national logistics. Vojno delo, 69(3), 280-302.

31. Tasić, J. (2018). Future trends and development laws rural tourism in Serbia and the world. Oditor - časopis za Menadžment, finansije i pravo, 4(3), 7-19.

32. Taylor, L., \& Kliestikova, J. (2018). The operational coherence of the workforceas-a-service pattern: Digitally mediated service work, the contingency of ondemand employment, and the low-income labor market. Psychosociological Issues in Human Resource Management, 6(1), 178-183.

33. Tuyls, R., \& Pera, A. (2019). Innovative Data-driven Smart Urban Ecosystems: Environmental Sustainability, Governance Networks, and the Cognitive Internet of Things. Geopolitics, History and International Relations, 11(1), 116-121.

34. Vujicic, M., \& Ristic L. (2012). European integration and rural development policy of the republic of Serbia and West Balkan countries. Bulgarian Journal of Agricultural Science, 18 (4), 519-530

35. Vochozka, M., Kliestik, T., Kliestikova, J., and Sion, G.(2018). Participating in a highly automated society: How artificial intelligence disrupts the job market. Economics, Management, and Financial Markets, 13(4), 57-62. 